\title{
Hubungan Kemampuan Representasi Visual dan Representasi Verbal Mahasiswa Pada Praktikum Morfologi Tumbuhan
}

\section{Correlation Of Undergraduate Students Visual Representation and Verbal Representation In Plant Morphology Practicum}

\author{
Stevia Ladisa ${ }^{1 *}$, Adi Rahmat ${ }^{2}$ \\ ${ }^{1}$ Magister Pendidikan Biologi, Universitas Pendidikan Indonesia. ${ }^{2}$ Departemen Pendidikan Biologi, \\ Universitas Pendidikan Indonesia. "Corespondent email: stevialadisa08@gmail.com
}

Received: 30 May 2020 | Accepted: 13 July 2020 | Published: 20 July 2020

\begin{abstract}
Abstrak. Morfologi tumbuhan membahas tentang peformance tumbuhan, serta pemahaman terminologi (istilah-istilah ilmiah) dari organ-organ tumbuhan baik vegetatif maupun generatif. Pada kegiatan praktikum morfologi tumbuhan mahasiswa dituntut untuk mengamati dan merepresentasikan hasil pengamatannya secara visual dalam bentuk gambar dan secara verbal dalam bentuk deskripsi. Tujuan dari penelitian ini adalah untuk mendeskripsikan hubungan kemampuan representasi visual dan representasi verbal dalam kegiatan praktikum morfologi tumbuhan. Penelitian ini dilaksanakan di salah satu perguruan tinggi negeri di Bandung Indonesia dengan 31 orang mahasiswa. Representasi visual dianalisis berdasarkan keautentikan gambar, kedetailan gambar, dan keterangan gambar. Kemampuan Representasi verbal dianalisis berdasarkan kejelasan dan kesesuaian deskripsi gambar dengan fakta, kelengkapan deskripsi gambar, dan terminologi. Hubungan kemampuan representasi visual dan representasi verbal mahasiswa dianalisis menggunakan software SPSS. Hasil penelitian menunjukkan bahwa kemampuan representasi visual dan representasi verbal mahasiswa pada materi batang berkorelasi lemah ( $\mathrm{r} 0,250$ dan $\mathrm{p}>0,05$ ), begitu juga dengan korelasi kemampuan representasi visual dan representasi verbal mahasiswa pada materi daun ( $\mathrm{r} 0,284$ dan $\mathrm{p}>0,05$ ). Hal ini menunjukan bahwa kemampuan representasi visual objek makroskopik yang baik tidak selalu menggambarkan kemampuan representasi verbal objek makroskopik yang baik.
\end{abstract}

Kata Kunci: Representasi visual, Representasi verbal

\begin{abstract}
Plant morphology describe about plant peformance and understanding the terminology (scientific terms) from plant organs both vegetative and generative. In the plant morphology practicum, undergraduate students are required to observe and represent their observations visually in the form of images and verbally in the form of descriptions. The aims of this study is to describe the correlation of visual representation and verbal representation in plant morphology practikum. This research was conducted at one of the state universities in Bandung Indonesia with 31 undergraduate students. Visual representation were analyzed based on the authenticity of the image, detail of the image, and description of the image. Verbal representation were analyzed based on the clarity and appropriateness of the image description with the facts, completeness description of the image, and terminology. The correlation of visual representation and verbal representation undergraduate students was analyzed using SPSS software. The results of this experiment describe that the ability of visual representation and verbal representation of undergraduate students on stem material has low correlation ( $r 0.250$ and $p$ > $0.05)$, as well as the correlation of visual representation and verbal representation undergraduate students on leaf material ( $r 0.284$ and $p>0.05$ ). Its describe that a good visual representation not always has a good verbal representation.
\end{abstract}

Keyword: Visual representation, Verbal representation

\section{PENDAHULUAN}

Morfologi tumbuhan merupakan salah satu cabang ilmu botani yang mendeskripsikan tentang bentuk, susunan dan struktur dari organ-organ tumbuhan. Deskripsi tentang morfologi tumbuhan adalah dasar yang digunakan untuk mengenal jenis suatu tumbuhan, sehingga 
morfologi tumbuhan sangat penting dalam penentuan batasan taksa suatu tumbuhan (Simpson, 2006). Pada mata kuliah Morfologi tumbuhan mengkaji mengenai karakter-karakter tumbuhan secara morfologi, serta pemahaman terminologi (istilah-istilah ilmiah) dari organ-organ tumbuhan baik vegetatif maupun generatif. Oleh karena itu pada perkuliahan morfologi tumbuhan mahasiswa secara khusus diarahkan untuk mampu memahami konsep dan pengetahuan dasar tentang terminologi ilmiah tumbuhan melalui kegiatan pengamatan langsung terhadap objek nyata yang bersifat makroskopik di laboratorium untuk mendapatkan pengetahuan faktual. Kegiatan praktikum merupakan kegiatan belajar mengajar dalam mengamati atau memanipulasi objek nyata dan bahan merupakan bagian penting dari pendidikan sains yang mengarah pada peningkatan prestasi, pemahaman, dan sikap ilmiah (attitude toward science), sehingga merupakan hal yang penting dalam pembelajaran sains (Abrahams dan Reiss, 2013; Abrahams dan Saglam, 2010; Haslam dan Hamilton, 2010).

Melalui kegiatan praktikum dapat meningkatkan pemahaman konsep mahasiswa (Abrahams dan Reiss, 2012). Pada kegiatan praktikum mahasiswa juga dituntut untuk dapat merepresentasi objek yang diamati, hal ini bertujuan agar mahasiswa mampu memahami tentang morfologi tumbuhan melalui kemampuan representasi serta dapat memanfaatkan pengetahuan tersebut untuk mempelajari hal-hal yang berkenaan dengan tumbuhan. Quillin dan Thomas (2015) mengatakan bahwa representasi dapat meningkatkan keterampilan pengamatan dan membantu mahasiswa dalam membangun pengetahuannya. Selain itu, hasil representasi objek makroskopik yang dibuat mahasiswa dapat menggambarkan tingkat pemahaman mahasiswa terhadap objek yang diamati berdasarkan pengetahuan faktual berbasis pengetahuan konseptual.

Informasi yang diperoleh selama pengamatan objek makroskopik dapat direpresentasikan secara verbal dan nonverbal berupa representasi visual. Representasi visual dan verbal berfungsi sebagai pembawa makna. Salah satu representasi visual yang dapat digunakan untuk merepresentasikan objek dalam kegiatan praktikum morfologi tumbuhan adalah gambar. Gambar adalah representasi visual yang menggambarkan semua jenis konten, baik struktur, hubungan dan proses yang dibuat dalam bentuk dua dimensi statis pada media apapun (Quillin dan Thomas, 2015). Representasi gambar dapat menyajikan informasi tentang pemahaman terhadap objek/fenomena yang diamati berkaitan dengan konsep yang dipelajari. Hal ini sesuai dengan pernyataan Ainsworth et al., (2011) bahwa representasi gambar yang dibuat oleh mahasiswa dapat menjelaskan pemahaman mahasiswa tersebut terhadap konsep yang dipelajari. Sedangkan representasi verbal merupakan representasi yang berisi kode atau istilah dari informasi visual. Kode atau istilah tersebut dapat disajikan dalam bentuk kata dan atau deskripsi yang mendukung informasi visual yang diperoleh (Paivio, 1991).

Representasi hasil pengamatan objek makroskopik pada praktikum morfologi tumbuhan dapat dilakukan secara visual ke dalam bentuk gambar dan secara verbal ke dalam sebuah deskripsi yang berupa penjelasan dari gambar hasil representasi visual. Paivio (1991) menyatakan bahwa informasi yang direpresentasikan dengan gambar dan teks akan lebih mudah dipahami dan dapat disimpan lebih lama dalam memori jangka panjang daripada informasi yang hanya direpresentasikan melalui gambar atau teks saja. Oleh sebab itu, pada praktikum morfologi tumbuhan mahasiswa dituntut untuk dapat merepresentasikan objek pengamatan secara visual dan verbal berdasarkan hasil pengamatan, akan tetapi fakta di lapangan mahasiswa masih kesulitan dalam merepresentasikan objek makroskopik secara visual dan verbal 
berdasarkan hasil pengamatan yang telah dilakukan. Akan tetapi mahasiswa sering menggunakan literatur dalam merepresentasikan objek makroskopik tersebut.

Padahal representasi visual dan verbal yang dibuat berdasarkan hasil pengamatan tersebut dapat menyajikan informasi tentang pemahaman mahasiswa terhadap objek yang diamati berkaitan dengan fakta dan konsep yang dipelajari. Hasil representasi yang dibuat dapat menjadi sarana untuk menganalisis dan menilai pemahaman tentang pembelajaran (Kose, 2008; Dikmenli, 2010). Teori dual coding menyatakan bahwa seseorang memiliki kemampuan yang bervariasi dalam representasi visual dan verbal, representasi tersebut dapat menjadi alat untuk merekam dan mengkomunikasikan informasi yang diperoleh dari objek pengamatan sehingga dapat dianalisis pemahamannya (Quilin dan Thomas, 2015). Berdasarkan hal ini maka dilakukan penelitian tentang hubungan representasi visual dan representasi verbal pada praktikum morfologi tumbuhan tentang materi batang dan daun. Penelitian ini bertujuan untuk menganalisis hubungan antara kemampuan representasi visual dan representasi verbal yang dimiliki mahasiswa pada praktikum morfologi tumbuhan tentang batang dan daun.

\section{METODE PENELITIAN}

Penelitian ini merupakan penelitian deskriptif yang dilaksanakan di Universitas Pendidikan Indonesia pada semester genap tahun akademik 2017/2018. Partisipan penelitian ini adalah 31 orang mahasiswa yang mengontrak perkuliahan morfologi tumbuhan dengan bobot perkuliahan 2 sks. Materi morfologi tumbuhan yang dideskripsikan dalam penelitian ini adalah materi tentang batang dan daun. Materi batang terdiri dari materi batang 1 tentang bentuk umum batang, materi batang 2 tentang pola percabangan batang dan materi batang 3 tentang modiikasi batang. Sedangkan materi daun terdiri dari materi daun 1 tentang perkembangan daun, materi daun 2 tentang bentuk umum daun, materi daun 3 tentang bentuk helaian, apeks, dan basal daun, materi daun 4 tentang tepi daun, materi daun 5 tentang pertulangan daun, materi daun 6 tentang daun tunggal daun majemuk, materi daun 7 tentang modiikasi daun dan materi daun 8 tentang filotaksis daun.

Kemampuan representasi visual mahasiswa dianalisis menggunakan rubrik penilaian gambar dengan indikator (1) keautentikan gambar, (2) kedetailan gambar, dan (3) keterangan gambar. Sedangkan kemampuan representasi verbal dianalisis berdasarkan indikator (1) kejelasan dan kesesuaian deskripsi gambar dengan fakta, (2) kelengkapan deskripsi gambar, dan (3) terminologi. Kemampuan mahasiswa dalam merepresentasikan objek makroskopik baik secara visual maupun verbal dapat dikelompokan berdasarkan Tabel 1. Hubungan kemampuan representasi visual dan kemampuan representasi verbal mahasiswa dianalisis berdasarkan hasil uji korelasi menggunakan sfotware SPSS.

Tabel 1. Kategorisasi Kemampuan Representasi Visual dan Representasi Verbal

\begin{tabular}{cc}
\hline Interval skor & Kategori \\
\hline $80-100$ & Sangat baik \\
$60-79$ & Baik \\
$40-59$ & Sedang \\
$20-39$ & Kurang \\
$0-19$ & Sangat kurang \\
\hline
\end{tabular}




\section{HASIL DAN PEMBAHASAN}

\section{Representasi Visual}

Hasil penelitian tentang kemampuan representasi visual objek makroskopik mahasiswa pada materi batang dan daun disajikan pada Gambar 1. Kemampuan representasi visual mahasiswa pada materi batang umumnya berada pada kategori baik, meskipun masih ada mahasiswa yang memiliki kemampuan representasi visual kategori kurang dan sedang. Hal ini menunjukan bahwa informasi-informasi yang diperoleh selama kegiatan praktikum sudah dapat direpresentasikan secara visual dengan kategori baik, informasi tersebut disajikan dalam hal keautentikan gambar, kedetailan gambar dan keterangan gambar.

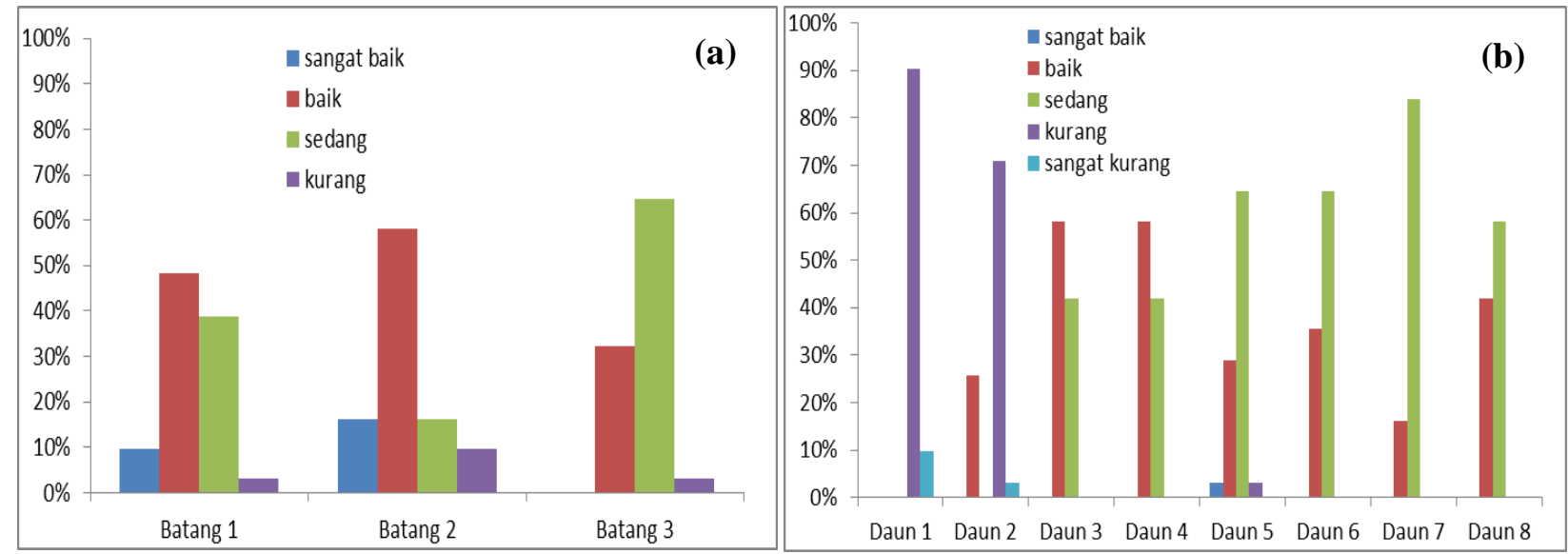

Gambar 1. Persentases Representasi Visual Mahasiswa Objek Makroskopik Visual: (a) Materi Batang dan (b) Materi Daun

Kemampuan representasi visual mahasiswa pada materi batang umumnya berada pada kategori sedang, meskipun sudah ada mahasiswa yang memiliki kemampuan representasi visual kategori baik. Kemampuan representasi visual objek makroskopik mahasiswa pada materi batang lebih tinggi dibandingkan materi daun pada praktikum morfologi tumbuhan. Lebih tingginya kemampuan representasi visual objek makroskopik materi batang daripada materi daun pada praktikum morfologi tumbuhan disebabkan karena materi daun yang harus diamati dan direpresentasikan pada saat praktikum memiliki objek makroskopik yang lebih banyak dan lebih kompleks daripada objek makroskopik batang.

Sementra kemampuan representasi visual mahasiswa pada materi daun umumnya berada pada kategori sedang. Hasil analisis tersebut menunjukan bahwa informasi-informasi yang telah diperoleh selama pengamatan pada kegiatan praktikum sudah dapat direpresentasikan secara visual kedalam bentuk gambar, walaupun gambar yang disajikan belum sepenuhnya sesuai dengan kriteria gambar yang baik dan benar. Hal ini juga menunjukan tidak semua informasi yang diperoleh selama pengamatan dapat direpresentasikan secara visual dengan baik. Quillin dan Thomas (2015) mengatakan bahwa kemampuan menggambar dapat bervariasi yang dipengaruhi oleh tingkat kesulitan, jumlah informasi dan abstraksi informasi yang akan direpresentasikan. Selain itu objek makroskopik tentang materi daun memilki lebih banyak fakta-fakta yang harus diamati, sehingga mahasiswa mengalami kesulitan dalam memroses fakta tersebut di memori kerjanya.

Sementara itu Moreno dan Park (2010) mengatakan bahwa mahasiswa hanya dapat memroses beberapa informasi pada satu waktu dalam memori kerjanya. Sehingga kemampuan mahasiswa dalam merepresentasikan objek makroskopik secara visual kedalam bentuk gambar 
juga dapat memberi gambaran tentang pemahaman mahasiswa tersebut terhadap informasiinformasi tentang objek makroskopik yang diperolehnya selama kegiatan praktikum, karena gambar hasil representasi visual yang dibuat mengacu tentang informasi-informasi apa saja yang telah diproses pada memori kerja dan disimpan pada memori jangka panjang (Reid, 2010), selanjutnya Kose (2008), dan Dikmenli (2011) mengatakan bahwa gambar hasil representasi visual mahasiswa dapat dijadikan sebagai salah satu alat untuk mengakses dan menilai pemahaman mahasiswa tentang informasi yang diperolehnya.

Selain dapat digunakan sebagai alat untuk mengakses dan menilai pemahaman mahasiswa, kemampuan mahasiswa dalam merepresentasikan objek makroskopik secara visual kedalam bentuk gambar juga merupakan salah satu bentuk keterampilan yang dapat terus dilatih, hal ini dapat dilihat dengan meningkatnya skor representasi visual objek makroskopik mahasiswa tentang materi daun pada setiap praktikum materi daun. Selanjutnya Clark dan Paivio (1991) yang mengatakan bahwa mekanisme teori dual coding yang megkaji tentang representasi verbal dan nonverbal (visual) merupakan mekanisme yang berkaitan dengan aspek kognisi manusia, keterampilan motorik dan emosi. Menggambar adalah suatu keterampilan proses yang dapat digunakan untuk mengkomunikasikan semua jenis konten, baik struktur maupun hubungan atau proses yang dibuat dalam bentuk dua dimensi (Quillin dan Thomas, 2015).

\section{Representasi Verbal}

Hasil penelitian tentang kemampuan representasi verbal mahasiswa pada materi batang dan daun disajikan pada Gambar 2. Kemampuan representasi verbal mahasiswa pada materi batang umumnya berada pada kategori sedang, meskipun masih ada mahasiswa yang memiliki kemampuan representasi verbal kategori kurang.

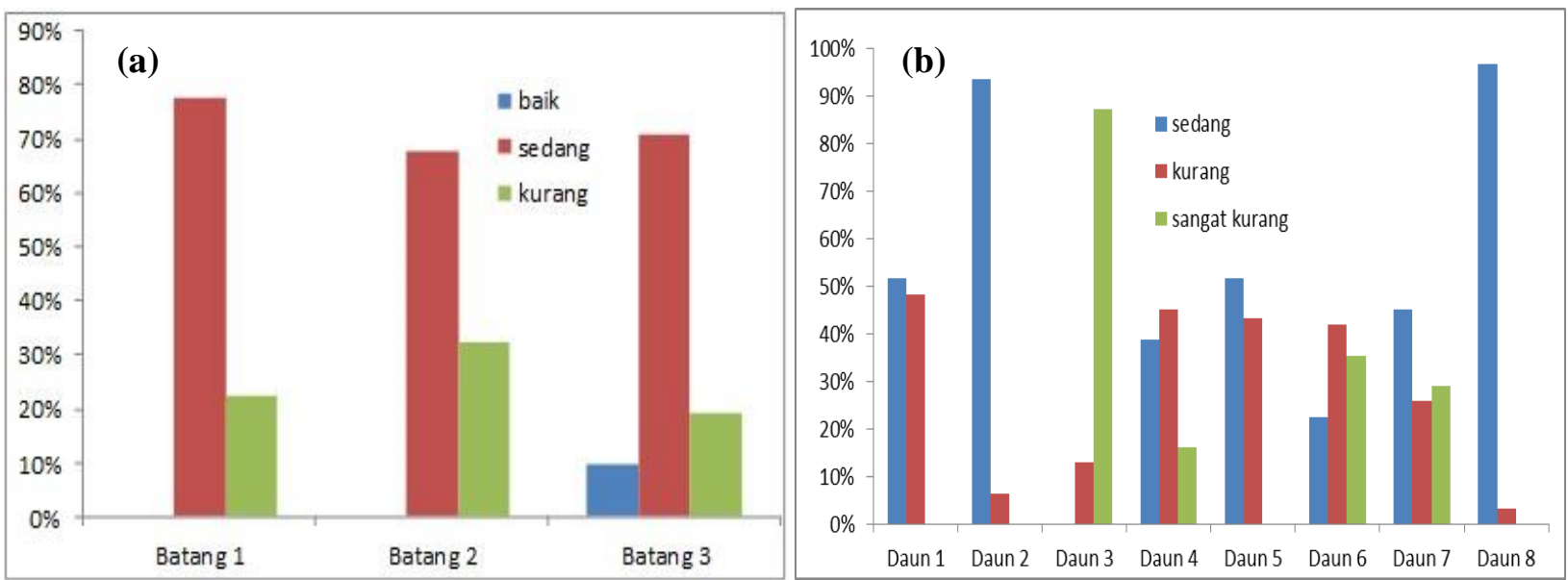

Gambar 2. Persentase Representasi Verbal Mahasiswa: (a) Materi Batang dan (b) Materi Daun

Kemampuan representasi verbal mahasiswa pada materi daun umumnya berada pada kategori sedang, meskipun masih ada mahasiswa yang memiliki kemampuan representasi verbal kategori kurang dan sangat kurang. Berdasarkan hasil penelitian yang telah dilakukan pada kegiatan praktikum morfologi tumbuhan tentang materi batang dan materi daun dapat diketahui bahwa kemampuan representasi verbal objek makroskopik mahasiswa pada materi batang lebih baik daripada materi daun. Hasil ini dibuktikan dengan tingginya skor kemampuan representasi verbal makroskopik yang diperoleh mahasiswa pada setiap sub materi batang daripada skor 
kemampuan representasi verbal makroskopik pada materi daun. Selain itu juga dapat dibuktikan dengan sudah adanya mahasiswa yang dapat mendeskripsikan gambar hasil pengamatannya tentang batang pada kategori baik, meskipun secara umum mahasiswa memiliki kemampuan representasi verbal pada kategori sedang.

Kemampuan representasi verbal objek makroskopik mahasiswa pada materi batang lebih tinggi daripada materi daun, hal ini dikarenakan materi daun memiliki materi yang lebih banyak daripada materi batang dan objek makroskopik pada materi daun juga lebih banyak daripada materi batang, sehingga juga terdapat lebih banyak terminologi tentang materi daun yang harus dideskripsikan mahasiswa. Paivio (1991) mengatakan bahwa jumlah kata-kata yang bersifat konkret dan kata-kata yang bersifat abstrak (istilah) juga dapat mempengaruhi kemampuan representasi verbal, dimana kata yang bersifat konkret lebih mudah dipahamai sehingga lebih mudah dideskripsikan daripada kata yang bersifat abstrak. Selain itu Solso et al., (2008) mengatakan bahwa jumlah kata-kata yang maknanya yang dapat diketahui oleh seseorang berkisar antara 20.000-40.000 kata dan memori rekognisi yang berperan dalam mengelolah dan menyimpan kata-kataberjumlah lebih besar dari jumlah tersebut, sehingga sebagian besar pengetahuan kita bersifat verbal.

Representasi yang telah dibuat mahasiswa, baik berupa representasi visual maupun representasi verbal dapat menunjukan pengetahuan dan pemahaman mahasiswa tersebut tentang objek makroskopik batang dan daun yang diamatinya. Sejalan dengan pendapat Brunswik, (1956); Rouse dan Morris, (1986) yang mengatakan bahwa representasi dapat mencerminkan model mental seseorang tentang suatu persepsi realitas dan terkait erat dengan kerangka pengetahuan seseorang dalam mendeskripsikan, menjelaskan dan memprediksi sesuatu, sehingga memiliki pengaruh penting pada pengembangan pengetahuan ilmiah seseorang. Quillin dan Thomas (2015) mengatakan bahwa kegiatan representasi dapat membantu mahasiswa dalam membangun pengetahuannya tentang materi yang dipelajari. Oleh sebab itu representasi visual maupun representasi verbal dapat dijadikan sebagai alat ukur pemahaman siswa tentang materi yang dipelajarinya.

\section{Korelasi Kemampuan Representasi Visual Objek Makroskopik dan Representasi Verbal Objek Makroskopik}

Uji korelasi ini dilakukan untuk melihat hubungan antara kemampuan representasi visual objek makroskopik dengan kemampuan representasi verbal objek makroskopik. Analisis korelasi antara representasi visual objek makroskopik dan representasi verbal objek makroskopik materi batang dan materi daun dapat dilihat pada Tabel 2 berikut.

Tabel 2. Korelasi Kemampuan Representasi Visual Objek Makroskopik dan Kemampuan Representasi Verbal Objek Makroskopik Materi Batang dan Materi Daun

\begin{tabular}{ccc}
\hline Korelasi & R & Sign. \\
\hline Representasi Visual - Representasi Verbal Batang & 0,250 & 0,175 \\
Representasi Visual - Representasi Verbal Daun & 0,284 & 0,122 \\
\hline
\end{tabular}

Berdasarkan Tabel 2 dapat dilihat bahwa korelasi antara kemampuan representasi visual objek makroskopik dan kemampuan representasi verbal objek makroskopik tentang materi batang dan materi daun menunjukan hubungan positif dengan kategori lemah dan tidak signifikan. Hal ini menunjukan bahwa kemampuan representasi visual objek makroskopik pada materi batang dan materi daun tidak berhubungan terhadap kemampuan representasi verbal objek 
makroskopiknya. Sejalan dengan yang dikatakan Paivio (1991), Paivio (2006); Meyer (2009) mengatakan bahwa proses representasi visual dan representasi verbal terjadi pada working memory visual dan verbal yang tidak selalu melibatkan koordinasi keduanya.

Korelasi yang tidak signifikan antara kemampuan representasi visual objek makroskopik dan kemampuan representasi verbal objek makroskopik menggambarkan bahwa tidak ada hubungan antara peningkatan atau penurunan kemampuan representasi visual objek makroskopik terhadap peningkatan atau penurunan kemampuan representasi verbal objek makroskopik atau dapat dikatakan bahwa kemampuan representasi visual objek makroskopik dan kemampuan representasi verbal objek makroskopik mahasiswa berdiri sendiri. Ishikawa dan Kastens (2005); Jalmo dan Suwandi (2018) mengatakan bahwa kemampuan representasi visual dan kemampuan representasi verbal memiliki korelasi lemah, yang artinya kemampuan representasi visual yang baik tidak dapat menggambarkan kemampuan representasi verbal yang baik pula.

\section{KESIMPULAN}

Hasil penelitian mendeskripsikan bahwa mahasiswa yang memiliki kemampuan representasi visual objek makroskopik yang baik tidak selalu memiliki representasi verbal objek makroskopik yang baik pula, atau dapat dikatakan bahwa kemampuan representasi visual objek makroskopik dan kemampuan representasi verbal objek makroskopik mahasiswa berdiri sendiri.

\section{UCAPAN TERIMA KASIH}

Ucapan terima kasih penulis sampaikan kepada semua pihak yang telah membantu dalam proses penelitian, spesial Ibu Dr. Kusdianti, M.Si selaku dosen mata kuliah morfologi tumbuhan serta rekan-rekan asisten praktikum yang telah membantu dalam proses penelitian.

\section{REFERENSI}

Abrahams, I., and Saglam, M. 2010. A Study of Teachers' Views on Practical Work in Secondary Schools in England and Wales. International Journal of Science Education, 32(6): 753-768.

Abrahams, I., and Reiss, M. J. 2012. Practical Work: Its Effectiveness in Primary and Secondary Scholl in England. Journal of Research in Science Teaching, 49(2): 1035-1055.

Abrahams, I. and Reiss, M. J. 2013. The Assessment of Practical Work In School Science. Journal of Science Education, 49(2): 209-251.

Ainsworth, S.E., Prain, V., and Tytler, R. 2011. Drawing To Learn In Science. University of Nottingham repository. Nottingham. 646 pp.

Brunswik, E. 1956. Perception and The Representative Design of Psychological Experiments. University of California Press, Berkeley California. 154 pp.

Clark, J. M., and Paivio, A. 1991. Dual Coding Theory and Education. Educational Psychology Review, 3(3): 255-258.

Dikmenli, M. 2010. Misconceptions of Cell Division Held By Student Teachers in Biology: a Drawing Analysis. Scientific Research and Essays, 5(2): 235-247. 
Haslam, C. Y. and Hamilton, R. J. 2010. Investigating the use of integrated instructions to reduce the cognitive load associated with doing practical work. International Journal of Science Education, 32(13): 1715-1737.

Ishikawa, T., and Kastens, K. A. 2005. Why Some Students Have Trouble With Maps and Other Spatial Representations. Journal of Geoscience Education, 53(2): 184-197.

Jalmo, T., and Suwandi, T. 2018. Biology Education Students' Mental Models on Genetic Concepts. Journal of Baltic Science Education, 17(3): 2538-7138.

Kose, S. 2008. Diagnosing Student Misconceptions: Using Drawings as a Research Method. World Applied Sciences Journal, 3(2): 283-293.

Mayer, R. E. 2009. Multi Media Learning Prinsip-Prinsip dan Software. Pustaka Pelajar, Yogyakarta. 300 hal.

Moreno, R., and Park, B. 2010. Cognitive Load Theory: Historical Development to Other Theories, in Plaas JL et al., (Eds), Cognitive Load Theory. Cambride University Press, Britania. 275 pp.

Paivio, A. 1991. Picture Superiority in Free Recall: Imagery or Dual Coding?. Cognitive Psychology, 5: 176-206.

Paivio, A. 2006. Dual Coding Theory and Education. Prosiding International Conference on Pathways to Literacy Achievement for High Poverty Children. Michigan, U.S. 29 September-1 Oktober 2006.

Quillin, K., and Thomas, S. 2015. Drawing-to-learn: A Framework for Using Drawings to Promote Mode-Based Reasoning in Biology. CBE-life Sciences Education, 14: 1-16.

Reid, D.J. 2010. The Role of Pictures in Learning Biology: Part 1, Perception and Observation. Journal of Biology Education, 24(3): 161-172.

Rouse, W.B., and Morris, N.M. 1986. On Looking Into The Black Box: Prospects and Limits in the Search for Mental Models. Psychological Bulletin, 100(3): 349-363.

Simpson, M.G. 2006. Plant Systematics. Elsevier Academic Press, New York. 754 pp.

Solso, R.L., Maclin, O.H., dan Maclin, M.K. 2008. Psikologi Kognitif (dialihbahasakan oleh Mikael Rahardanto \& Kristianto Batuadji). Penerbit Erlangga, Jakarta. 325 hal.

\footnotetext{
Authors:

Stevia Ladisa, Magister Pendidikan Biologi, Universitas Pendidikan Indonesia, Jl. Dr. Setiabudi No. 229, Bandung (40154), Indonesia, email: stevialadisa08@gmail.com

Adi Rahmat, Departemen Pendidikan Biologi, Universitas Pendidikan Indonesia, Jl. Dr. Setiabudi No. 229, Bandung (40154), Indonesia, email: adirahmat@upi.com

This is an open-access article distributed under the terms of the Creative Commons Attribution License, which permits unrestricted use, distribution and reproduction in any medium, provided the original author and source are credited. (http://creativecommons.org/licenses/by/4.0/).

How to cite this article:

Ladisa, S., and Rahmat, A. 2020. Correlation of undergraduate students visual representation and verbal representation in plant morphology practicum. Simbiosa, 9(1): 60-67. Doi. http://dx.doi.org/10.33373/simbio.v9i1.2430.
} 